\title{
APLIKASI PAPERLESS LIBRARY DAN PENGUKURAN DAMPAK DENGAN MODEL IS- IMPACT
}

\author{
Rahmandani Herlambang, Husni Thamrin* \\ Program Studi Informatika \\ Universitas Muhammadiyah Surakarta \\ Surakarta \\ *husni.thamrin@ums.ac.id
}

\begin{abstract}
Abstrak-Perpustakaan digital adalah kumpulan benda digital termasuk pustaka buku, organisasi dari koleksi informasi beserta layanan, serta cara mengakses dengan tidak terbatas jarak dan waktu. misalnya situs web perpustakaan. Pelanggaran hak cipta pada pustaka digital sangat mungkin terjadi dan menjadi masalah serius karena benda digital mudah digandakan. Namun, hal tersebut dapat dicegah dengan solusi mengkonversi pustaka buku berformat $p d f /$ mobi/epub ke bentuk gambar dan memberikan watermark. Seperti yang diterapkan pada pengembangan aplikasi perpustakaan digital oleh penulis untuk melindungi hak cipta pustaka. Fitur tersebut adalah salah satu keunggulan dari sistem yang dikembangkan, selain tampilan responsif pada platform desktop atau mobile. Terdapat fitur baca pustaka dengan tampilan buku digital, untuk pustaka open access bersifat unlimited untuk pembaca, sedangkan closed access bersifat terbatas untuk jumlah pembaca berdasarkan jumlah eksemplar pustaka yang disediakan. Aplikasi telah diuji dan diterapkan di Universitas Muhammadiyah Kalimantan Timur. Hasil pengujian keberhasilan sistem informasi dengan model IS-IMPACT menunjukkan bahwa aplikasi sudah bermanfaat serta dapat digunakan untuk mengelola dan mengakses pustaka digital tanpa melakukan pelanggaran hak cipta
\end{abstract}

Kata Kunci: perpustakaan digital, paperless, bak cipta, IS-Impact

\section{Pendahuluan}

Perpustakaan digital adalah kumpulan benda digital, termasuk teks, video, audio, beserta metode akses dan pemeliharaan koleksi, Fox 1998 dalam Witten [1]. Selain merupakan kumpulan benda digital, istilah perpustakaan digital mencakup organisasi dari koleksi informasi beserta layanan yang terkait termasuk bagaimana pustaka diakses [2], [3]. Lebih dari itu, kegiatan perpustakaan digital mencakup proses pembuatan, penggunaan, dan pencarian konten digital [4] .

Pengembangan perpustakaan digital memberikan keuntungan karena perpustakaan digital dapat "dikunjungi" dengan tidak berbatas jarak dan waktu [5], sebagai contoh akses dan pengambilan informasi secara online [6]. Menyediakan satu titik akses ke berbagai sumber yang terdistribusi secara mandiri [7]. Situs web perpustakaan adalah contoh definisi ini [8]. Perpustakaan semacam itu haruslah menarik secara visual, ergonomis mudah digunakan, menggabungkan kenyamanan serta kemampuan pencarian yang hebat, menawarkan fasilitas penjelajahan yang kaya dan alami [1].

Namun, terdapat masalah besar dalam pengembangan perpustakaan digital yaitu hak cipta. Sesuai dengan pasal 40 UU No.28 Tahun 2014, ciptaan yang mendapat perlindungan hak cipta salah satunya adalah buku dan semua hasil karya tulis [9]. Pustaka dengan hak cipta hanya bisa dibaca dan tidak dapat digandakan atau disunting [10]. Penggandaan dan pengalihmediaan pustaka merupakan masalah di banyak perpustakaan Indonesia [11]. Salah satunya adalah pembajakan buku [9], koleksi digital yang dimiliki perpustakaan [12]. Pustaka digital sangat mudah untuk digandakan karena belum adanya regulasi di Indonesia yang mengatur perpustakaan digital. Padahal, penghormatan hak cipta dapat mendorong kreativitas penulis untuk menciptakan karya-karya berkualitas [13].

Untuk mengatasi permasalahan hak cipta atas pustaka, penulis mengembangkan aplikasi perpustakaan digital yang memperhatikan hak cipta pada pustaka digital. Aplikasi ini melakukan pengelolaan pustaka dan konten digital berbasis website. Aplikasi diuji di perpustakaan Universitas Muhammadiyah Kalimantan Timur, sebuah universitas yang memiliki slogan IT Based Paperless University. Hasil pengujian menunjukkan bahwa aplikasi dapat digunakan untuk mengelola pustaka digital, mengakses pustaka digital tanpa melakukan pelanggaran hak cipta.

\section{Metode}

\section{a. Metode Penelitian Sistem}

Metode penelitian yang digunakan adalah metode penelitian kualitatif. Penelitian kualitatif bersifat reflektif, interpretatif, deskriptif [14]. Disimpulkan bahwa penelitian kualitatif semakin menemukan identitasnya sendiri 
ketika dilihat dalam hal tujuan dan prosedur pendekatan kuantitatif dan kritis untuk komunikasi [15].

\section{b. Metode Pengembangan Sistem}

Metode pengembangan sistem perpustakan digital sesuai SDLC (Systems Development Life Cycle) dengan metode prototype. Prototipe adalah model fisik kerja dari sebuah sistem atau subsistem, yang berfungsi sebagai versi awal dari sistem [16], sedangkan Sprague \& McNurlin dalam Pliskin prototipe sebagai proses berulang dari menciptakan dengan cepat [17]. Metode prototype bisa digambarkan pada gambar 1.

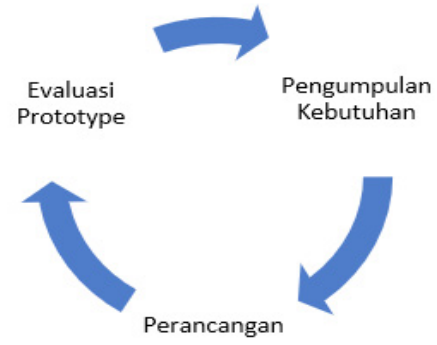

Gambar 1. Pengembangan dengan Metode Prototype

Langkah-langkah pengembangan sistem dalam prototyping seperti yang diidentifikasi oleh Pressman meliputi [18]:

1. Pengumpulan kebutuhan

Tahapan pengumpulan kebutuhan dilakukan dengan mewawancarai atau diskusi dengan beberapa level aktor terkait seperti kepala IT UMKT, dosen pembimbing, serta pegawai perpustakaan UMKT/pustakawan. Hal tersebut dilakukan untuk mendefinisikan secara garis besar kebutuhan keseluruhan sistem serta kebutuhan fungsional dan non fungsional. Data yang sudah terkumpul disesuaikan dengan tujuan untuk mensukseskan salah satu visimisi UMKT "IT-Based Paperless".

2. Desain cepat

Perancangan dilakukan sesuai definisi kebutuhan yang sudah terkumpul. Tahap ini melakukan desain template frontend/tampilan aplikasi website dengan mengutamakan kenyamanan pengguna pada platform desktop maupun mobile. Desain yang sudah dibuat selanjutnya akan dievaluasi kembali oleh aktor terkait.

3. Membangun prototype/mengkodekan sistem

Pada tahap ini prototype yang telah disepakati akan dikonversi ke dalam bahasa pemrograman python dan diterapkan pada framework Django sebagai backend atau sistem yang akan memproses berbagai logic algoritma program serta mengolah data. Beberapa algoritma penting akan dibuat seperti teknik untuk melindungi hak cipta pustaka dengan cara memberi watermark dan mengubah format pustaka dari $p d f$, mobi, epub ke gambar supaya tidak bisa di-copy dan diunduh. Postgresql digunakan untuk database sesuai kesepakatan dengan kepala IT UMKT.

Cara kerja program:

a. Anggota perpustakaan login sesuai user password.

b. Grouping, anggota perpustakaan akan diseleksi berdasarkan jurusan.

c. Pilih atau cari artikel. d. Menampilkan hasil pilihan artikel atau pencarian artikel.

e. Jika artikel bersifat open acces bisa dibaca oleh semua user / anggota perpustakaan/mahasiswa, pustaka bersifat unlimited.

f. Jika jumlah artikel yang bersifat close access belum ada yang membaca atau sedang dibaca, tetapi menyisakan slot untuk membaca, maka user bisa membaca artikel tersebut.

g. Jika jumlah artikel yang bersifat close access sedang dibaca semua di waktu yang bersamaan, maka user yang ingin membaca harus menunggu atau mencari artikel lain. Sebagai gambaran jika ada 5 buku hanya bisa dibaca 5 user saja.

h. Jika user sudah selesai membaca artikel yang dilindungi hak cipta, maka user yang sudah mengantri bisa membaca artikel.

i. Jika sudah selesai membaca artikel, logout untuk keluar aplikasi

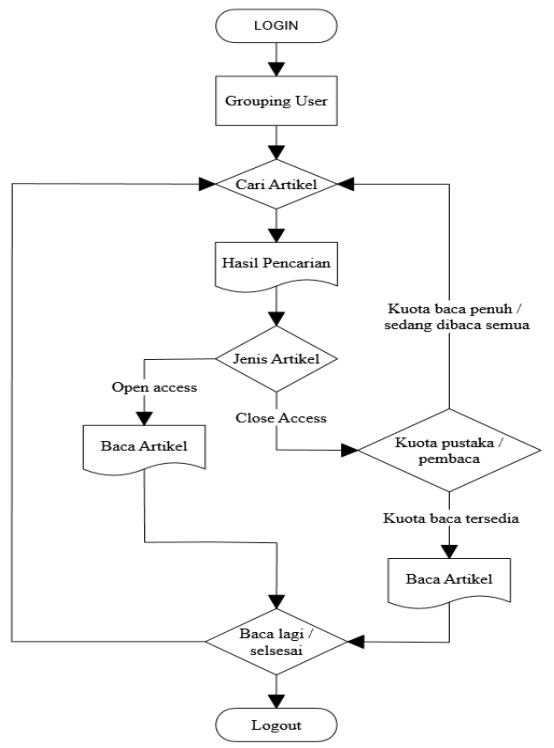

Gambar 2. Diagram Alir Konsep Sistem

4. Menguji dan evaluasi sistem

Pengujian sistem menggunakan metode black box testing. Pada tahap ini kepala IT UMKT, dosen pembimbing dan pustakawan UMKT melakukan evaluasi terhadap sistem yang sudah dibuat. Apakah sesuai harapan dan kebutuhan, apabila belum sesuai maka akan dilakukan proses tahap 4 dan 5 .

5. Penerapan sistem

Penerapan sistem dilakukan ke UMKT setelah aplikasi paperless library selesai pada semua tahap. Pada kegiatan ini dilakukan konfigurasi ke server supaya aplikasi website bisa diakses secara online dengan alamat https://paperless.umkt.ac.id .

6. Model pengukuran keberhasilan sistem informasi Model yang digunakan untuk mengukur keberhasilan penerapan sistem perputakaan digital mengadopsi teori model pengukuran IS-Impact/model gable. pendekatan kuantitatif data dikumpulkan melalui kuesioner dengan 37 pertanyaan dan 4 dimensi. Meliputi dampak individu, dampak organisasi, kualitas sistem, dan kualitas informasi [19]. 


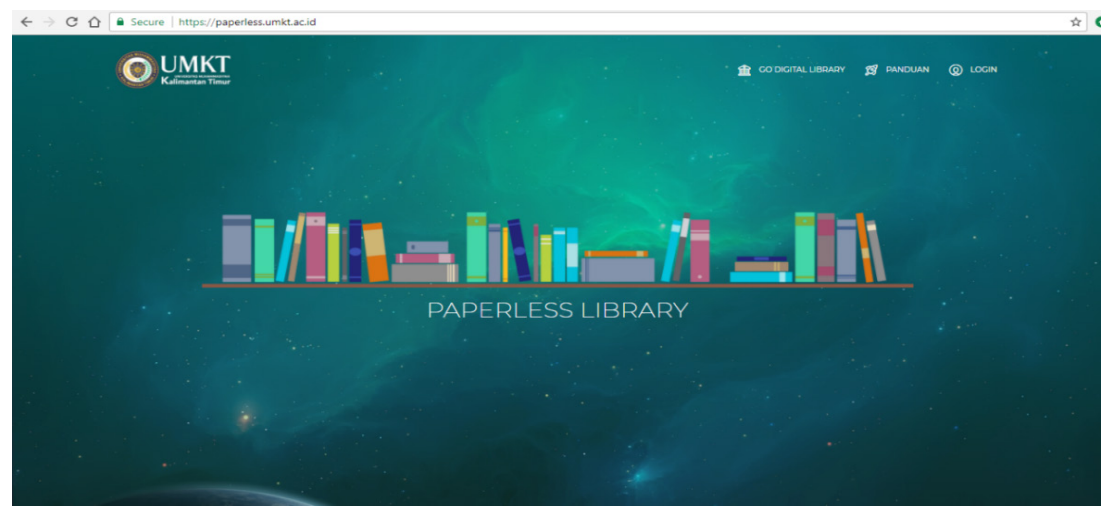

Gambar 3. Halaman Awal "PAPERLESS LIBRARY"
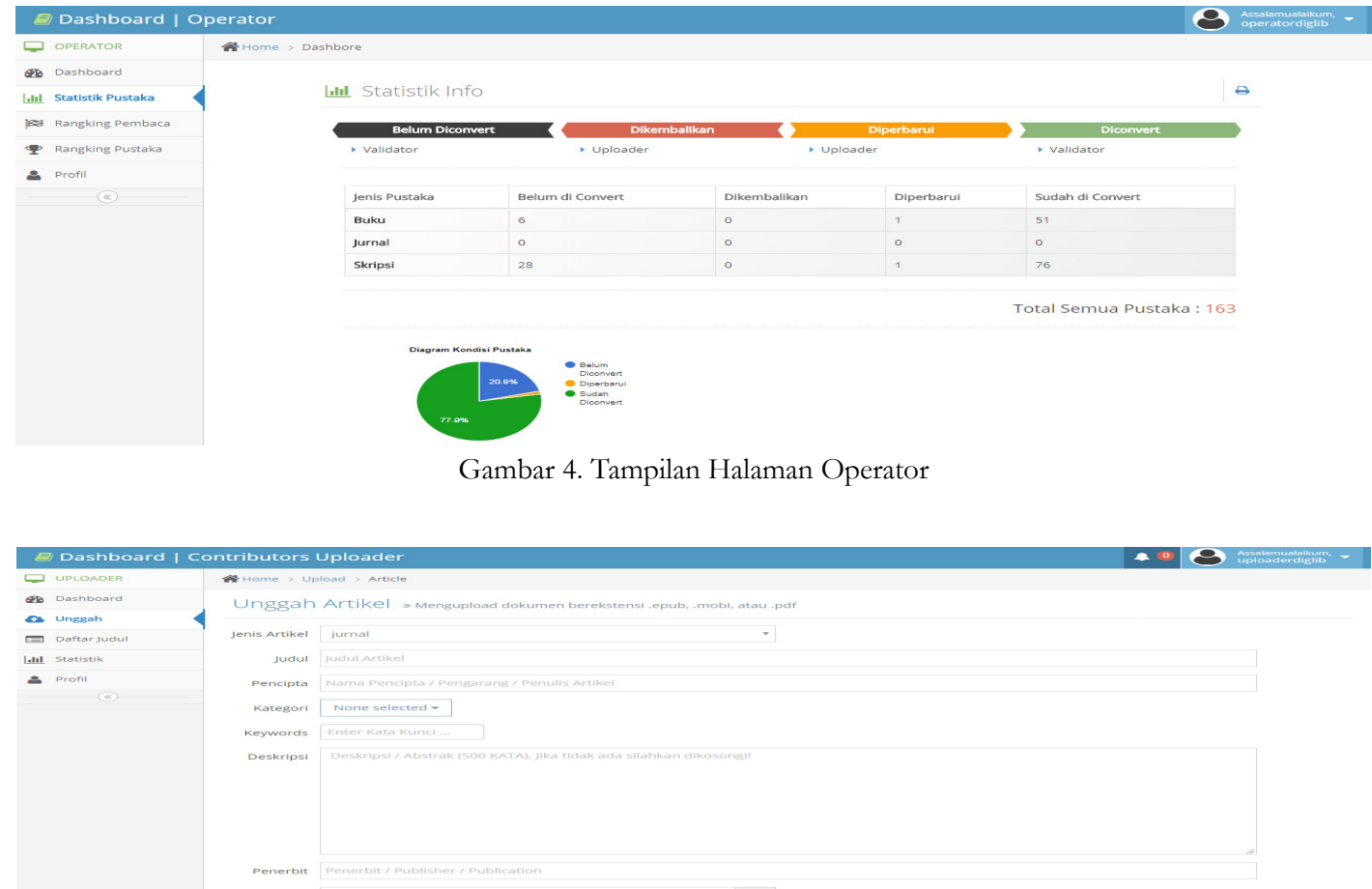

Gambar 5. Tampilan Halaman Uploader

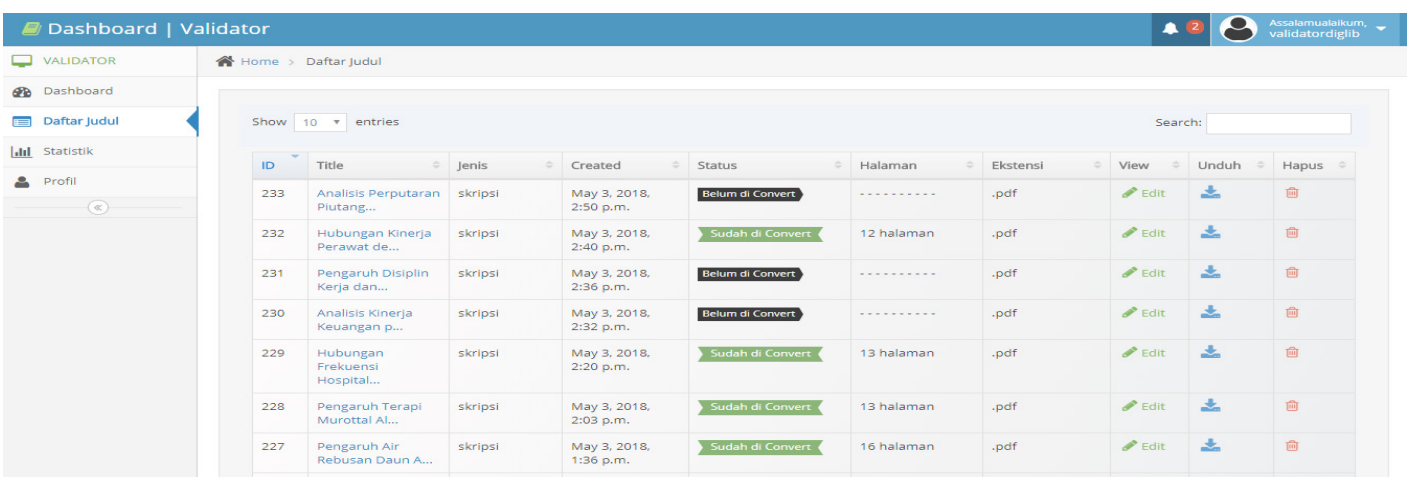

Gambar 6. Tampilan Halaman Validator 


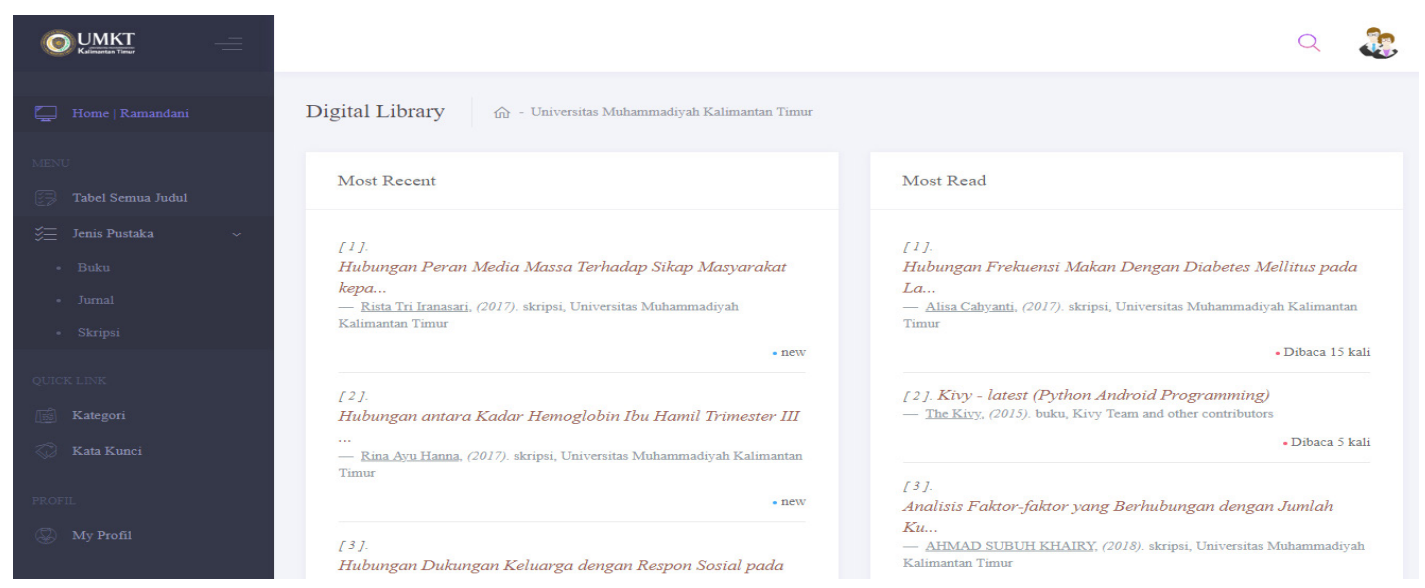

Gambar 7. Tampilan Halaman anggota perpustakaan/pengunjung

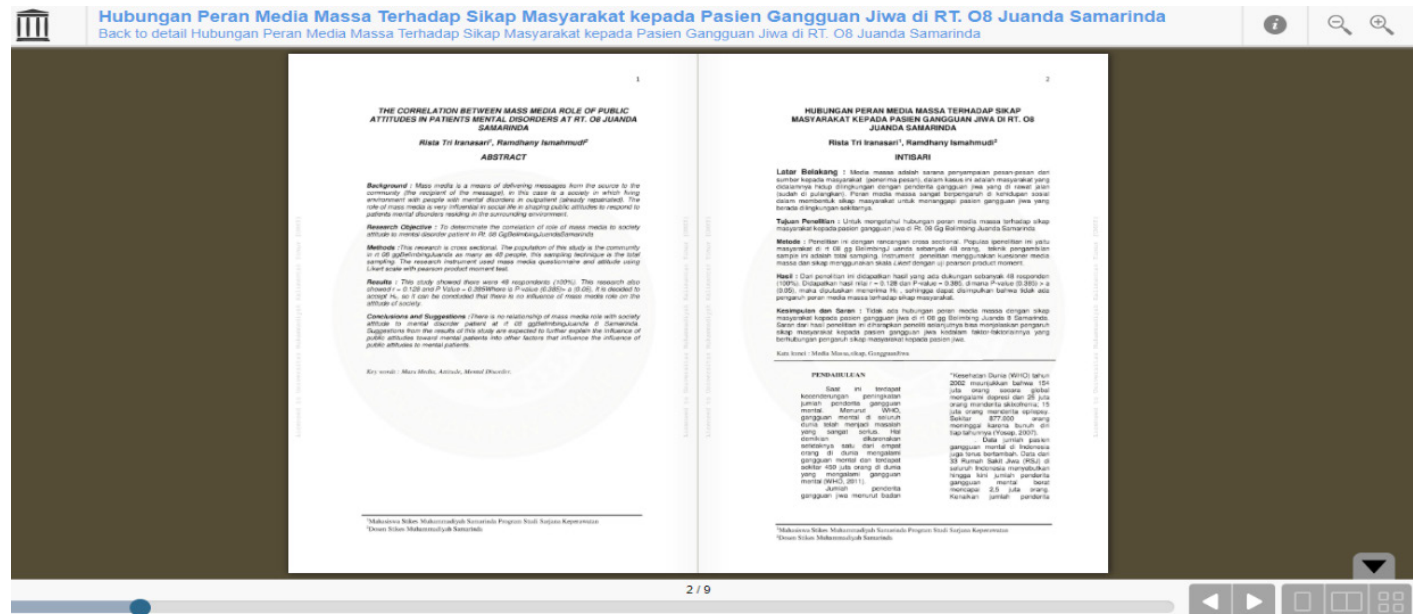

Gambar 8. Tampilan Halaman "Baca"

\section{Hasil Dan Pembahasan}

\section{a. Implementasi Sistem}

Hasil dari penelitian ini adalah sistem informasi pengelolaan pustaka dan konten digital berbasis website untuk sebuah perpustakaan digital dengan memperhatikan hak cipta. Sistem yang dibuat sudah diterapkan di Universitas Muhammadiyah Kalimantan Timur. Sistem berupa sebuah website yang bisa diakses secara online dengan alamat https://paperless.umkt.ac.id . terdapat empat level aktor pengguna, terdiri dari operator, uploader, validator, dan anggota perpustakaan/mahasiswa.

Keunggulan yang ditonjolkan sistem perpustakaan digital ini adalah tampilan responsif di platform sistem operasi desktop dan mobile. Fitur unggulan di level pengguna anggota perpustakaan seperti tampilan buku digital pada halaman "baca" yang bisa menyesuaikan dengan ukuran layar sistem operasi mobile/desktop. Namun, untuk membaca koleksi pustaka hanya bisa diakses oleh anggota perpustakaan yang sudah login, anggota/ user yang tidak login hanya bisa melihat sampai metadata saja. disini pembaca dicegah untuk mengunduh file untuk semua koleksi pustaka. Selain itu terdapat fitur quick link/ pencarian cepat berdasarkan kategori dan kata kunci. Tersedia juga pencarian hebat berdasarkan input user yang hasilnya akan di hightlight.
Fitur utama pada level "uploader" adalah mengunggah pustaka dan mengisikan metadata, serta memperbarui file jika pustaka dikembalikan oleh "validator".

Fitur utama pada level "validator" yaitu memvalidasi pustaka dan mencocokan metadata yang diunggah uploader dengan isi file, kemudian mengkonversi dari pustaka berformat .pdf, .epub, .mobi ke bentuk gambar yang sudah diberi watermark. Level pengguna "validator" dapat mengembalikan pustaka jika file pustaka yang diunggah oleh "uploader" salah atau tidak sesuai dengan metadata, diasumsikan bahwa terjadi buman error uploader salah memilih file, serta dapat menyisipkan sebuah pesan khusus untuk "uploader", sehingga "uploader" bisa memperbarui file tanpa megisikan ulang metadata.

Terdapat level pengguna “operator" yang dikhususkan untuk melihat semua statistik jumlah pustaka, status pustaka yang sudah di-upload, belum dikonversi, sudah dikonversi, dikembalikan, dan diperbaiki. Operator juga dapat melihat rangking anggota perpustakaan yang sering membaca di perpustakaan digital secara online, selain itu terdapat fitur melihat rangking pustaka yang sering dibaca. Level pengguna operator adalah pimpinan perpustakaan atau civitas UMKT yang mempunyai hak untuk memonitor traffic perpustakaan digital. Berikut adalah tampilan perpustakaan digital dengan nama aplikasi "PAPERLESS LIBRARY" ditunjukan pada gambar 3, 4, $5,6,7,8$. 
Tabel 1. Pengujian Black Box pada login

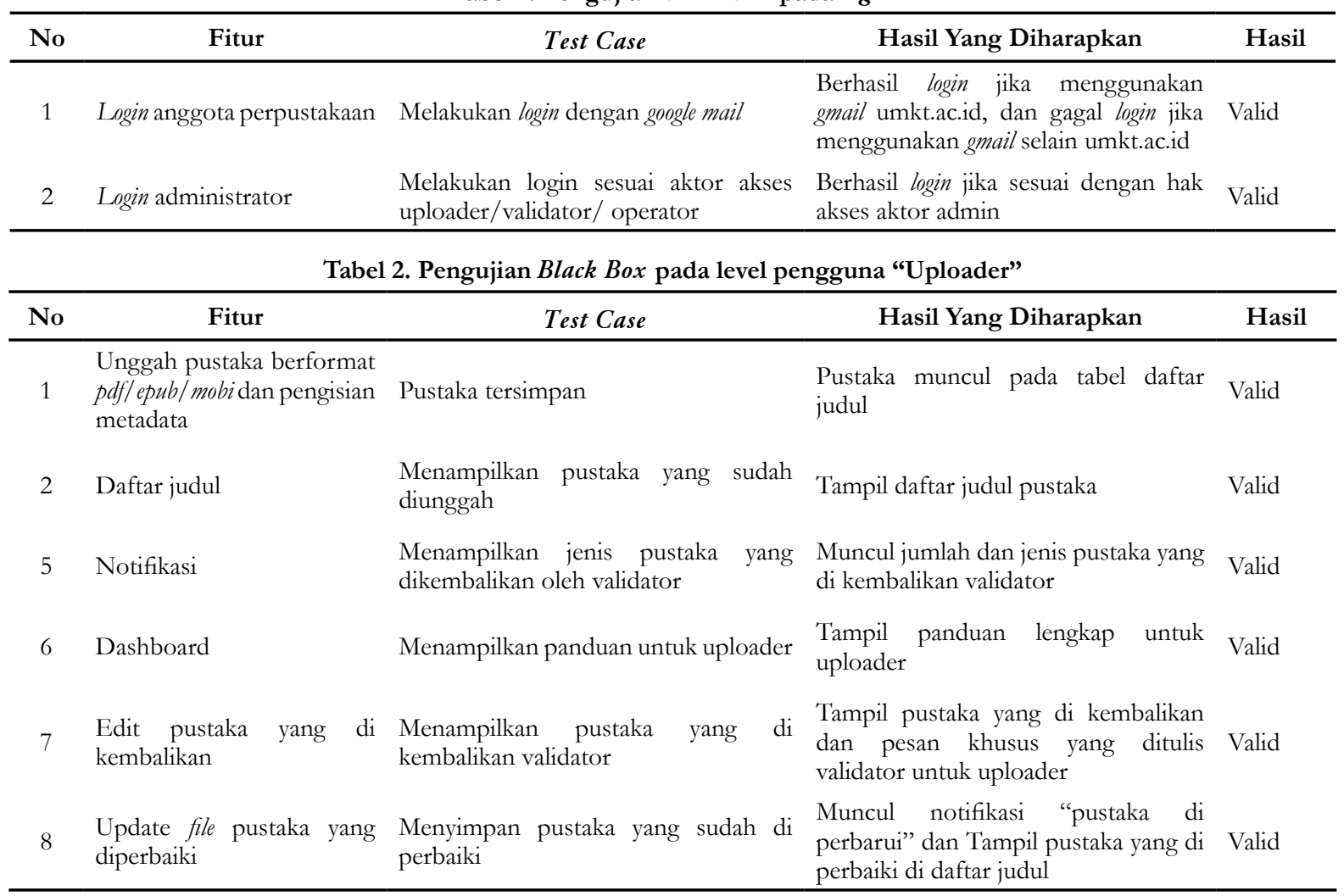

Tabel 3. Pengujian Black Box pada level pengguna "Validator"

\begin{tabular}{|c|c|c|c|c|}
\hline No & Fitur & Test Case & Hasil Yang Diharapkan & Hasil \\
\hline 1 & Daftar judul & $\begin{array}{l}\text { Menampilkan pustaka yang belum } \\
\text { dikonvert, sudah dikonvert, diperbarui } \\
\text { dikembalikan }\end{array}$ & $\begin{array}{l}\text { Tampil daftar judul pustaka belum } \\
\text { dikonvert, dikembalikan, diperbarui, } \\
\text { sudah dikonvert }\end{array}$ & Valid \\
\hline 2 & Statistik & Menampilkan statistik pustaka & $\begin{array}{l}\text { Tampil statistik pustaka berdasarkan } \\
\text { jenis pustaka dan status pustaka }\end{array}$ & Valid \\
\hline 3 & Notifikasi & $\begin{array}{l}\text { Menampilkan jenis pustaka yang } \\
\text { diperbarui uploader }\end{array}$ & $\begin{array}{l}\text { Muncul jumlah dan jenis pustaka yang } \\
\text { di perbarui uploader }\end{array}$ & Valid \\
\hline 4 & Edit pustaka & Menampilkan pustaka & $\begin{array}{l}\text { Tampil pustaka yang belum/ } \\
\text { dikonvert/dikembalikan/diperbarui/ } \\
\text { sudah dikonvert }\end{array}$ & Valid \\
\hline 5 & Simpan pustaka & Menyimpan pustaka & $\begin{array}{l}\text { Pustaka bisa dibaca di book view, dan } \\
\text { tampil pada daftar pustaka dengan } \\
\text { status sudah dikonvert }\end{array}$ & Valid \\
\hline 6 & Kembalikan pustaka & Mengembalikan pustaka & $\begin{array}{l}\text { Muncul tambah catatan dan pustaka } \\
\text { akan berubah status menjadi } \\
\text { dikembalikan }\end{array}$ & Valid \\
\hline 7 & Download pustaka & Mengunduh pustaka & $\begin{array}{l}\text { Pustaka tersimpan dalam sistem } \\
\text { operasi validator }\end{array}$ & Valid \\
\hline 8 & Hapus pustaka & Menghapus pustaka & Pustaka terhapus dari daftar judul & Valid \\
\hline
\end{tabular}


Tabel 4. Pengujian Black Box pada level anggota perpustakaan/pengunjung

\begin{tabular}{|c|c|c|c|c|}
\hline No & Fitur & Test Case & Hasil Yang Diharapkan & Hasil \\
\hline 1 & Tabel semua judul & Menampilkan semua judul pustaka & Tampil semua judul pustaka & Valid \\
\hline 2 & $\begin{array}{l}\text { Jenis pustaka buku/jurnal/ } \\
\text { skripsi }\end{array}$ & $\begin{array}{l}\text { Menampilkan jenis pustaka buku/ } \\
\text { jurnal/skripsi }\end{array}$ & $\begin{array}{l}\text { Tampil jenis pustaka buku/jurnal/ } \\
\text { skripsi secara grouping berdasarkan } \\
\text { tahun, bulan. maupun berdasarkan } \\
\text { jurusan khusus untuk skripsi }\end{array}$ & Valid \\
\hline 3 & Kategori & $\begin{array}{l}\text { Menampilkan pustaka sesuai kategori } \\
\text { akademik }\end{array}$ & $\begin{array}{l}\text { Tampil pustaka sesuai kategori } \\
\text { akademik }\end{array}$ & Valid \\
\hline 4 & Kata kunci & Menampilkan kata kunci & $\begin{array}{l}\text { Tampil kata kunci dalam pustaka } \\
\text { secara grouping dan urut sesuai abjad }\end{array}$ & Valid \\
\hline 5 & Pencarian & Menampilkan pustaka yang dicari & $\begin{array}{l}\text { Muncul pustaka yang di cari sesuai } \\
\text { input yang dimasukan oleh user. Muncul } \\
\text { hightlight jika pustaka ditemukan }\end{array}$ & Valid \\
\hline 7 & Baca & Menampilkan pustaka & $\begin{array}{l}\text { Tampil pustaka dengan tampilan buku } \\
\text { digital }\end{array}$ & Valid \\
\hline 8 & Profil & $\begin{array}{l}\text { Menyimpan profil } \\
\text { perpustakaan }\end{array}$ & $\begin{array}{l}\text { Tampil profil nama dan email anggota } \\
\text { perpustakaan, jika sudah login }\end{array}$ & Valid \\
\hline
\end{tabular}

Tabel 5. Pengujian Black Box pada level pengguna “Operator"

\begin{tabular}{cccc}
\hline No & Fitur & Test Case & Hasil Yang Diharapkan \\
\hline 1 & Statistik pustaka & Menampilkan statistik pustaka & $\begin{array}{l}\text { Tampil statistik pustaka berdasarkan } \\
\text { jenis pustaka , status pustaka, dan } \\
\text { diagram charts }\end{array}$ \\
2 & Rangking pembaca & Menampilkan rangking pembaca & $\begin{array}{l}\text { Tampil rangking pembaca yang sering } \\
\text { membaca }\end{array}$ \\
& Rangking pustaka & Menampilkan rangking pustaka & $\begin{array}{l}\text { Tampil rangking pustaka yang sering } \\
\text { dibaca }\end{array}$ \\
\hline
\end{tabular}

Tabel 6. Hasil pengukuran keberhasilan dengan model IS-Impact/Gable

\begin{tabular}{clcccc}
\hline No & \multicolumn{1}{c}{ Fitur } & Jumlah Responden & Jumlah Pertanyaan & Positif & Negatif \\
\hline 1 & Kualitas Informasi & 7 & 10 & $90 \%$ & $10 \%$ \\
2 & Kualitas Sistem & 5 & 15 & $97,3 \%$ & $2,6 \%$ \\
3 & Dampak Organisasi & 6 & 8 & $93,7 \%$ & $6,2 \%$ \\
4 & Dampak Individu & 5 & 4 & $90 \%$ & $10 \%$ \\
\hline
\end{tabular}

\section{b. Pengujian Black Box Sistem}

Keuntungan utama dari pengujian black box adalah penguji tidak perlu memiliki pengetahuan khusus bahasa pemrograman, implementasi, dan dilakukan dari sudut pandang pengguna. Keuntungan signifikan dari pengujian black box adalah membantu mengungkap ambiguitas atau ketidakkonsistenan dalam spesifikasi persyaratan [20]. Pengujian black box dilakukan pada produk yang benar-benar selesai [21], [22]so any technique aiming at reducing software-testing costs is likely to reduce software development costs. Proposed by NASA in 1994, the Modified Condition/Decision Coverage (MC/DC. Tabel 1, 2, 3, 4, 5 menunjukkan hasil pengujian black box sistem perpustakan digital.

\section{c. Hasil Pengukuran Keberhasilan Sistem Informasi dengan Model IS-Impact}

Hasil pengukuran model IS-Impact/Gable, dilakukan dengan memberikan 37 kuesioner dalam 4 dimensi. Yaitu, dampak individu bermakna sejauh mana telah mempengaruhi kemampuan dan keefektifan atas nama organisasi dari pengguna, dampak organisasi bermakna sejauh mana sistem memiliki peningkatan dan kapabilitas organisasi, kualitas informasi bermakna ukuran kualitas informasi yang dihasilkan sistem, kualitas sistem bermakna ukuran kinerja dari teknis dan desain perspektif.

Terdapat beberapa pertanyaan dari setiap dimensi dengan jumlah berbeda-beda. Meliputi 4 pertanyaan pada dimensi dampak individu, 8 pertanyaan pada dimensi dampak organisasi, 15 pertanyaan pada dimensi kualitas sistem, 10 pertanyaan pada dimensi kualitas informasi. Responden adalah aktor dari uploader, validator, operator dan kepala IT UMKT. Terdapat 4 jawaban yang masuk dalam 2 golongan positif dan negatif. Dalam golongan positif terdapat jawaban sangat setuju, dan setuju. Sedangkan golongan negatif berupa jawaban tidak setuju dan sangat tidak setuju. Hasil dari jawaban kuesioner dalam dimensi ditotal dan dipresentase untuk menunjukkan hasil persen positif dan negatif, ditunjukkan pada table 6 .

Makna dari tabel 6. Pada dimensi kualitas informasi dengan jumlah responden 7 dan 10 pertanyaan, didapatkan 
hasil 90\% respons positif dan 10\% respons negatif. Pada dimensi kualitas sistem dengan jumlah responden 5 dan 15 pertanyaan didapatkan hasil $97,3 \%$ positif dan $2,6 \%$ negatif. Kemudian pada dampak organisasi dengan jumlah responden 6 dan jumlah pertanyan 8 didapatkan $93,7 \%$ positif dan $6,2 \%$ negatif. Untuk dampak individu dengan 5 responden dan 4 pertanyaan didapatkan 90\% positif dan $10 \%$ negatif.

Pengukuran keberhasilan sistem sangatlah penting dan sudah dilakukan oleh banyak peneliti dengan berbedabeda model. beberapa metode seperti metode kualitatif dengan mengukur secara taksiran seperti yang dilakukan Al chanani dan Thamrin [23]. Terdapat pula kerangka PIECES untuk menguji kepuasan pengguna seperti yang dilakukan Supriyatna dan Maria [24].

Pembahasan

Sistem perpustakaan digital sudah diterapkan pada server dengan alamat https://paperless.umkt. ac.id, sehingga dapat diakses secara online. Tampilan perpustakaan digital diciptakan responsive pada sistem operasi desktop atau mobile, dengan desain modern maka sangat mudah digunakan oleh user, selain itu menawarkan kenyamanan pengguna serta kemampuan pencarian pustaka secara cepat dan penjelajahan kelompok pustaka terstruktur.

Keunggulan dari level pengguna anggota perpustakaan adalah fitur "baca" berbentuk buku digital dengan mengutamakan tampilan kenyamanan saat membaca. Terdapat pustaka open access yang bersifat unlimited atau bisa dibaca oleh semua anggota perpustakaan dan close access yaitu bersifat terbatas bagi pembaca sesuai jumlah eksemplar pustaka yang disediakan. Untuk menjaga hak cipta pustaka, maka setiap pustaka diberi watermark kemudian dikonversi ke gambar supaya tidak dapat disalin atau digandakan. Tidak disediakan fitur download pustaka, namun jika pengguna mempunyai kemampuan untuk mengunduh gambar pustaka maka masih ada watermark yang tidak mudah untuk dihilangkan. Akan tetapi untuk mengakses fitur "baca", seorang user diharuskan untuk login dengan google mail dengan indikatordomain"@umkt. ac.id" yang diizinkan masuk, selain domain tersebut tidak mungkin untuk bisa login karena sudah dicegah oleh google atau dianggap bukan anggota perpustakaan UMKT.

Level pengguna "uploader" yang bertugas mengunggah pustaka dan "validator" yang akan memvalidasi pustaka untuk dinyatakan layak publish atau dikembalikan karena file pustaka tidak konsisten dengan metadata. Uploader dapat memperbaiki pustaka yang dikembalikan dengan bantuan membaca pesan spesifik kesalahan yang dikirimkan oleh validator, sehingga memudahkan uploader menemukan kesalahannya dan tidak perlu menuliskan ulang metadata serta meningkatkan kinerja uploader.

Level tertinggi adalah operator, yang mempunyai hak melihat seluruh statistik pada perpustkaan digital. Seperti statistik semua jumlah pustaka buku, skripsi, jurnal dengan sepesifikasi status belum dikonversi, sudah dikonversi, dikembalikan, dan diperbarui. Operator juga dapat melihat rangking teratas pustaka yang sering dibaca oleh anggota perpustakaan. Fitur yang menarik adalah rangking nama anggota perpustakaan yang sering membaca online, fitur ini dapat dimanfaatkan untuk memberikan penghargaan/ reward kepada anggota perpustakaan dengan rangking teratas yang sering membaca, supaya minat baca semakin tinggi.

Manfaat penerapan perpustakaan digital "Paperless Library" bagi Universitas Muhammadiyah Kalimantan Timur diharapkan mampu berkontribusi dalam mendukung aktivitas akademik serta pembangunan sistem IT untuk meningkatkan ranking universitas baik dari lembaga akreditasi nasional, Webometric maupun QS World University. Serta menciptakan lingkungan melek teknologi untuk mahasiswa, sesuai dengan moto "TT-Based Paperless University" UMKT mengembangkan sistem perpustakaan digital.

Terdapat peluang bisnis untuk mengembangkan perpustakaan digital ini, yaitu sebuah instansi pengembang perpustakaan digital dapat bekerjasama dengan developer penerbit buku akademis maupun non akademis untuk memperkaya koleksi pustaka. Dengan cara pihak developer sebagai aktor "uploader" yang mempunyai hak mengunggah pustaka sesuai perjanjian berapa pustaka yang dibeli oleh instansi, sedangkan pihak instansi sebagai aktor "validator" untuk memastikan buku sesuai dengan jumlah perjanjian dan mencocokan konsistensi metadata dengan file. Pustaka yang sudah dibeli hanya bisa dimiliki secara digital oleh mahasiswa sesuai jurusan akademis atau hanya bisa dibaca oleh satu user untuk setiap pustaka sesuai jumlah eksemplar seperti konsep penjualan buku tradisional.

\section{Penutup}

Perpustakaan digital dengan nama "PAPERLESS LIBRARY UMKT" telah selesai secara 100\% sesuai dengan kebutuhan dan ikut mensukseskan moto UMKT "TT-Based Paperless". Setelah uji black box testing secara fungsional sistem tidak mengalami bug/error.

Berdasarkan hasil pengukuran kemanfaatan dengan model IS-IMPACT bahwa kualitas informasi menunjukan $90 \%$ positif dan $10 \%$ negatif, kualitas sistem 97,3\% positif dan 2,6\% negatif. Sedangkan dampak kemanfaatan terhadap organisasi $93,7 \%$ positif dan $6,2 \%$ negatif. Dampak kemanfaatan terhadap individu $90 \%$ positif dan 10\% negatif. Dengan demikian, disimpulkan bahwa 4 dimensi pengukuran model IS-IMPACT pada setiap indikator menunjukan hasil rata-rata diatas $90 \%$ hasil positif, yang berarti bahwa aplikasi perpustakaan digital bermanfaat

Namun dimasa depan perlu di ukur tingkat kesuskesan sistem informasi seperti kualitas sistem, kualitas pelayanan, kualitas informasi dan kepuasan pengguna, dengan model lain. salah satunya adalah model Delone \& McLean. Sebab kualitas informasi, sistem dan pelayanan sangat berpengaruh positif pada pengguna dan kepuasan pengguna, selanjutya akan berpengaruh positif pada "net benefit" atau hasil [25], [26].

\section{Daftar Pustaka}

[1] I. H. Witten, R. J. McNab, S. J. Boddie, and D. Bainbridge, "Greenstone: a comprehensive opensource digital library software system," Proc. Fifth ACM Conf. Digit. Libr. 02-07 June, pp. 113-121, 2000.

[2] W. Y. Arms, "Digital libraries," Commun. ACM, 
vol. 38, no. 4, pp. 23-28, 1995.

[3] M. Lesk, Practical Digital Libraries: Books, bytes, and bucks. San Francisco, Calif.: Morgan Kaufmann Publishers, 1997.

[4] C. Borgman, I. Sølvberg, and L. (Eds. . Kovács, "Fourth DELOS Workshop . Evaluation of Digital Libraries : Testbeds, Measurements, and Metrics," no. June, 2002.

[5] B. Sloan, "Service perspectives for the digital library remote reference services," Libr. Trends, vol. 47, no. 1, pp. 117-143, 1998.

[6] S. Sood and V. Sreenivasulu, "Overhauling LISc curriculum with a slant to digital age: preparing library information centres and information professionals to the XXIst century," in Proceedings of 49th FID Pre-Conference Education and Training, 1998, pp. 112-18.

[7] A. Paepcke et al., "Using distributed objects for digital library interoperability," Computer (Long. Beach. Calif)., vol. 29, no. 5, pp. 61-68, 1996.

[8] L. Francisco-Revilla, F. Shipman, R. Furuta, U. Karadkar, and A. Arora, "Managing change on the web," Proc. first ACM/IEEE-CS Jt. Conf. Digit. Libr. - JCDL '01, pp. 67-76, 2001.

[9] U. Undang-Undang Republik Indonesia Nomor 28 tentang Hak Cipta, "Dewan Perwakilan Rakyat Republik Indonesia,” 2014.

[10] Susanto, "Desain dan Standar Perpustakaan Digital," J. Pustak. Indones., vol. 10, no. 2, pp. 1723, 2010.

[11] S. Wisda Pradipta and A. Permana, "UPAYA PENERAPAN HAK CIPTA TERHADAP PEMANFAATAN KOLEKSI BUKAN BUKU DI PERPUSTAKAAN DAERAH PROVINSI JAWA TENGAH," vol. 1, no. 1, 2012.

[12] D. Kusmawan, "Perlindungan Hak Cipta Atas Buku," Perspektif, vol. 19, no. 2, pp. 137-143, 2014.

[13] S. Rumani, "Tinjauan Yuridis Pelaksanaan Hak Cipta dalam Open Access Informasi," vol. 5, no. 2, pp. 111-123, 2016.

[14] H.-W. Lara, B. S. William, S. G. Leslie, and G. Rhonda, "Qualitative research methods for psychologists: Introduction through empirical studies," in An Assimilation Analysis of Psychotherapy: Responsibility for "Being There," Academic Press, 2006, p. 512.

[15] J. W. Chesebro and D. J. Borisoff, "What makes qualitative research qualitative?," Qual. Res. Reports Commun., vol. 8, no. 1, pp. 3-14, 2007.
[16] P. M. Ogedebe and B. P. Jacob, "Software Prototyping : A Strategy to Use When User Lacks Data Processing Experience," vol. 2, no. 6, pp. 219-224, 2012.

[17] N. Pliskin and P. Shoval, "End-user prototyping: sophisticated users supporting system development," ACM SIGMIS Database, vol. 18, pp. 7-17, 1987.

[18] R. . Pressman, Software engineerng: A practitioner's approach. McGraw - Hill Publishing Company. New York, 1987.

[19] G. G. Gable, D. Sedera, and T. Chan, "Reconceptualizing Information System Success: The IS-Impact Measurement Model *," J. Assoc. Inf. Syst., vol. 9, no. 7, pp. 377-408, 2008.

[20] S. Nidhra and J. Dondeti, "Black Box and White Box Testing Techniques - A Literature Review," Int. J. Embed. Syst. Appl., vol. 2, no. 2, pp. 29-50, 2012.

[21] P. Mitra, S. Chatterjee, and N. Ali, "Graphical analysis of $\mathrm{MC} / \mathrm{DC}$ using automated software testing," Int. Conf. Electron. Comput. Technol., pp. 145-149, 2011.

[22] T. Murnane and K. Reed, "On the Effectiveness of Mutation Analysis As a Black Box Testing Technique," Proc. 13th Aust. Conf. Softw. Eng., p. 12--, 2001.

[23] U. Al chanani and H. Thamrin, "Pengembangan Sistem Monitoring Layanan Tata Usaha dan Analisis Kemanfaatannya: Studi Kasus di Fakultas Komunikasi dan Informatika," no. 2, pp. 114-121, 2018.

[24] A. Supriyatna and V. Maria, "Analisis Tingkat Kepuasan Pengguna dan Tingkat Kepentingan Penerapan Sistem Informasi DJP Online dengan Kerangka PIECES," Khazanah Inform. J. Ilmu Komput. dan Inform., vol. 3, no. 2, pp. 88-94, 2017.

[25] W. H. Delone and E. R. Mclean, “The DeLone and McLean Model of Information Systems Success," J. Manag. Inf. Syst., vol. 19, no. 4, pp. 9-30, 2003.

[26] T. Mcgill, V. Hoobs, and J. Klobas, "User Developed Applications and Information System Success: A Test od DeLone and McLean's Model," Informations Resour. Manag. J., vol. 16(1), no. January, pp. 24-45, 2003. 